\title{
An Exploration of Factors that Motivate Human Rights Workers in Areas of Armed Conflict in the Philippines
}

\author{
John Francis Hernandez \\ Jan Nikko Dela Paz \\ Ethan Cedric Chua \\ Mendiola Teng-Calleja \\ Ateneo de Manila University
}

\begin{abstract}
This study examined the experiences and motivation of human rights workers (HRWs) in areas affected by armed conflict in the Philippines. Six human rights workers from Karapatan responded to semi-structured interviews. Karapatan is a Philippine NGO whose mission is to uphold human rights and document instances of human rights violations. The results described the risks experienced by human rights workers in conflict afflicted areas in the country. Intrinsic factors that motivate HRWs to continuously engage in human rights work despite facing adverse situations include altruism, belief that they are advocating a just cause, feeling a sense of fulfillment, and strongly identifying with their work. Findings likewise show that human rights workers draw strength from the relationships that they have with their partner communities. They are motivated to match the courage of community members (tumbasan ang tapang), and are strengthened by the strong and reciprocal bonds that they have with the communities that they serve. Implications on selecting, preparing, developing and providing organizational support to human rights workers are discussed.
\end{abstract}

Keywords: human rights workers, community, armed conflict, intrinsic motivation, Philippines

Armed conflict has been prevalent in the Philippines for decades (Daluz, 2015; United Nations, 2015). Several active militant groups such as the Moro Islamic Liberation Front (MILF), Moro National

Correspondence concerning this article can be addressed to Mendiola Teng-Calleja. Email: mcalleja@ateneo.edu

Published online: 30 June 2020 
Liberation Front (MNLF), and the Communist Party of the PhilippinesNew People's Army (CPP-NPA) are present in the country. Recent conflicts include the Mamasapano encounter where several Philippine National Police-Special Action Force (PNP-SAF) personnel and members of opposing militant groups were killed, the Lumad ${ }^{1}$ killings, and similar armed encounters in the different parts of the country (for more detailed accounts, see Amnesty International, 2017; Karapatan, 2015).

With armed conflict comes violations of human rights (Human Rights Watch, 2012). The current focus of conversations on human rights violations in the country are alleged extrajudicial killings, torture, and incarcerations in the urban areas related to the government's war on drugs. However, human rights violations committed in the context of armed conflict remain prevalent in different parts of the Philippines (Indigenous voices in Asia, 2017; "Report: Philippines Dominates," 2017; US Department of State, 2017).

Due to the prevailing conflict and volatile security situation in the country, human rights workers (HRWs) in areas with armed conflict are highly susceptible to various risks as they perform their duties. Generally, humanitarian workers, including those focusing on human rights, experience physical injury and threats to mental health (McFarlane, 2004; Sheik et al., 2000). Despite the important role they play in upholding human rights and promoting peace, there is a dearth of research that examines the motivations of human rights workers to operate in conflict-affected areas.

Recent studies on motivation and engagement in humanitarian work in high-risk areas focused on the experiences of health workers (e.g., Greenberg et al., 2018; Tassel \& Flett, 2011). On the other hand, research that analyzed voluntary risk-taking in humanitarian work captured diverse experiences of humanitarian workers in varying types of aid work that operate in both international and national settings (e.g., Roth, 2015; Sheik et al., 2000). This study addresses the gaps in the literature in two ways. First, it examines the risks faced by HRWs from the perspective of HRWs working in a specific milieu: rural areas in the Philippines, a developing country that had been experiencing decades-long armed conflict. Second, it puts specific

1 A group of indigenous people in Mindanao 
focus on the motivation of HRWs in areas affected by armed conflict. We argue that there will be nuances in the experiences of human rights workers as compared to other humanitarian workers (e.g., health professionals or international humanitarian workers) as their work entails documenting rights violations of groups involved in armed conflict in a country where they themselves are organically located.

\section{Armed Conflict in the Philippines}

The Uppsala Conflict Data Program (UCDP), an initiative that has produced and documented data on conflict for more than 20 years, differentiates areas experiencing armed conflict based on fatalities resulting from political incompatibilities of armed organized groups (Strand \& Dahl, 2010). UCDP defines an armed conflict as a "contested incompatibility that concerns government and/or territory over which the use of armed force between the military forces of two parties, of which at least one is the government of a state, has resulted in at least 25 battle-related deaths each year" (Uppsala Conflict Data Program, 2005, p.3). The Philippines was tagged as one of the countries experiencing internal armed conflict with at least 1,00o battle-related deaths from 1998 until 2008 (Strand \& Dahl, 2010). However, the internal armed conflict in the country started decades before 1998 and is still ongoing.

According to a report published by the US Department of State (2017), groups with organized armies that have been engaged in decades-long conflict with the Philippine government include Muslim separatists (e.g., MILF and MNLF), communist insurgents (CPP-NPA), and terrorist groups (e.g., Maute Group). Most, if not all, human rights issues are related to these groups in armed conflict with the state and include "killings by security forces, vigilantes and others allegedly connected to the government, and by insurgents; torture and abuse of prisoners and detainees by security forces; often harsh and life threatening prison conditions; warrantless arrests by security forces and cases of apparent government disregard for legal rights and due process; political prisoners; killings of and threats against journalists; official corruption and abuse of power; threats of violence against human rights activists; violence against women; and forced labor" (US 
Department of State, 2017, p. 1).

Providing services to those affected by the aforementioned issues as well as documenting and forming public opinion through campaigns and advocacy describe the focal functional areas of human rights work (Karapatan, 2007). These services include mustering resources such as legal support to victims of torture, relatives of the disappeared, and those subjected to extra-judicial killings; as well as forming factfinding missions and quick reaction teams to immediately respond to and investigate human rights violations (Karapatan, 2007). These functional responsibilities embedded in the work of HRWs naturally come with job-related risks.

\section{Risks Faced by Humanitarian and Human Rights Workers}

As previously mentioned, research that has analyzed voluntary risk-taking in humanitarian work captured diverse experiences of humanitarian workers in varying types of aid work that involve both international and national operations (e.g., Roth, 2015; Sheik et al., 2000). As such, the literature that will be presented in this section describes the risks faced by workers in high-risk areas and describes experiences of humanitarian or aid workers, within which HRWs belong to (Roth, 2015).

There are numerous risks humanitarian workers take when they choose to be deployed or volunteer in conflict-affected areas. These risks can be classified as either external or internal in nature (Connorton, Perry, Hemenway, \& Miller, 2012). External risks are among the most apparent and believed to be the largest contributor to the mortality rate of civilians who work in conflict-affected areas (Sheik et al., 2000). These risks include intentional violence (e.g., getting caught in a crossfire, being intentionally murdered, carjacking, kidnapping, and robbery), motor vehicle accidents, and natural causes (e.g., disease). Among the three forms of risks, intentional violence was found to be the cause of the overwhelming majority of reported deaths (Sheik et al., 2000).

Internal risks, although seemingly fewer compared to external risks, still have considerable effects on the lives of humanitarian workers (McFarlane, 2004). These risks are more challenging to 
observe compared to external risks and are therefore more difficult to address. Mental health problems (e.g., PTSD, burnout, depression, anxiety, and alcohol abuse) constitute most of the internal risks and can manifest during or after deployment (Connorton et al., 2012; Eiksson, Kemp, Gorsuch, Hoke, \& Foy, 2001; Holtz, Salama, Cardozo, \& Gotway, 2002; Musa \& Hamid, 2008). Post-traumatic stress disorder (PTSD) was seen as one of the most common mental health problems experienced by these workers, and it has only been given some attention by researchers and organizations involved in humanitarian work recently (Connorton et al., 2012; Eiksson et al., 2001; McFarlane, 2004).

The high risk involved in doing humanitarian work in general, which arguably is greater in human rights work, makes one wonder why HRWs choose to voluntarily be subjected to such work conditions. Studies on risk usually frame risk as negative and should be avoided (Roth, 2015). Thus, it is interesting to know what motivates HRWs to work in areas with armed conflict despite awareness of the risks they face.

\section{Motivation in Humanitarian and Human Rights Work}

Individuals are motivated differently when engaging in work (Deci \& Ryan, 2008). There are those who tend to be more externally motivated, where motivation relies on factors outside of the individual such as pay and recognition (Menguito, 2017). Others are more internally motivated, or they work for the enjoyment and fulfillment experienced through work (Franco, 2008). Literature that describes the motivation of Filipino workers describes them as motivated by both factors with greater weight on those that are intrinsic in nature (e.g., Franco, 2008; Ilagan, Hechanova, Co, \& Pleyto, 2014).

Similar emphasis on factors that intrinsically motivate humanitarian workers were found in humanitarian/aid-related literature. Tassel and Flett (2011) conducted a study among humanitarian health workers in areas that endanger their lives and personal well-being. Using the lens of self-determination theory, they found that health workers initially engage in humanitarian work to fulfill individual wants and needs such as gaining a sense of competence and 
being connected to others (introjected motivation). However, these workers continue with this type of work because of the internalization of particular values (identified motivation) such as justice and moral obligation as well as values inherent to a helping profession (i.e., being health professionals). On the other hand, literature that looked at the motivation of humanitarian workers (including human rights workers) to work in risky areas found that they do so because of the perceived challenge, meaningfulness, and urgency of aid work (Roth, 2015). Aid workers were described to be attracted to this kind of work despite working "on the edge" due to their capacity to make a difference and to be exposed to foreign cultures and exotic places (Roth, 2015).

Although there have been numerous studies on what motivates Filipino workers, the sector represented in this literature is mostly white collar workers in corporations whose working conditions are very different from HRWs. Similarly, recent studies on motivation among humanitarian workers in high risk areas highlight the experiences of health professionals or of aid workers in varying types of aid work that operate in international assignments. Thus, this study seeks to contribute to current knowledge on the motivations of human rights workers by answering the following questions:

1. What motivates HRWs to work in areas affected by armed conflict?

2. What are the risks faced by HRWs in the Philippines from the HRW's perspective?

\section{METHOD}

This study used interviews to gather data from human rights workers in areas affected by armed conflict. Participants were from Karapatan: Alliance for Advancement of People's Rights, one of the longest-running non-government organizations (NGO) in the Philippines that focuses on human rights (Karapatan, 2007). Karapatan HRWs voluntarily conduct fact-finding missions in areas experiencing armed conflict. The succeeding section provides a more detailed description of the organization and the participants as well as the procedures and materials used for the research. 


\section{Karapatan: Alliance for Advancement of People's Rights}

Karapatan is an alliance of organizations, programs, institutions, and individuals that seek to promote and protect human rights in the Philippines (Karapatan, 2007). Its founding leaders and members have been at the forefront of the human rights struggle in the country since the time of Martial Law in the early 1970s. It is one of the few organizations that conduct fact-finding missions in areas where there are reported violations of human rights (Karapatan, 2007). They operate primarily in areas with an occurrence of active conflict between armed government and anti-government troops. This has led to experiences of harassment and even alleged killings of some of their human rights workers. For instance, in 2003, Eden Marcellana, the Secretary-General of Karapatan Sounthern Tagalog, was allegedly summarily executed in Oriental Mindoro (Tayao-Juego, 2014). In 2015, Human Rights in ASEAN, published an open letter addressed to the Secretary of the Department of Justice stating that "Karapatan's leaders and staff members in the Southern Mindanao region are constantly under attack, as they experience surveillance, threats and harassment from the military. Human rights defenders attribute these violations to the intensification of military operations, especially in Mindanao, where $60 \%$ of the total troops of the Armed Forces of the Philippines are deployed" (par. 5).

\section{Participants}

The six participants of this study were recruited using purposive sampling. All were HRWs employed by Karapatan and were selected based on the following inclusion criteria:

1. Must have been an employee of Karapatan for at least three years;

2. Must have been deployed to an active conflict area at least three times while working for Karapatan;

3. The total deployment time should be at least thirty days; and

4. Is considered a worker in good standing by Karapatan leaders.

The minimum of three years of service was required to ensure that the participants have more experiences working in the field and have 
had the chance to fully immerse themselves in the communities they visit. The minimum number of times the participants were deployed was also determined because it was essential for the participants to be engaged in the experience of armed conflict in the country. The participant must also be in good standing within the organization. This means that the service they provided must be significant and substantial with respect to the organization and their partner communities. There is limited demographic information that can be provided about the participants (except that they conformed with the inclusion criteria) because of the sensitivity of the study and the conditions posited by the organization.

\section{Data Collection Instruments}

Interviews were conducted to gather data on the experiences of these workers. Questions related to their previous work experience and how they became involved with Karapatan (e.g., "Please share your work experience before getting involved with Karapatan" and "How did you know about Karapatan?") were asked at the beginning of the interview as part of rapport building. These were followed by questions related to their experiences in areas affected by conflict. Examples of these questions are, "What are your thoughts about working in active conflict areas?," "What made you choose this particular kind of work?," "Please describe any particular experience where you thought or felt your life was in imminent danger when you were working in an active conflict area," and "What helped you overcome your fear?"

\section{Data Collection Procedures}

A formal request to participate in the study with a project concept paper was given to Karapatan's Executive Director as part of the gatekeeping process. Upon approval of the request, a pilot interview was conducted to test the clarity and validity of the questions. Revisions were made to address any ambiguous or unreliable questions in the guide. A total of six employees of Karapatan who met the inclusion criteria participated in the study through the appointed contact person within the organization. Interviews were conducted in venues 
identified and preferred by the interviewees.

All interviews began with an introduction that stated the rights of the participants to confidentiality, anonymity, and to withdraw from the study at any point during and after the interviews. The interviewers also took note of the participants' non-verbal expressions and actions to determine level of comfort in sharing information. The researchers noted that contrary to expectations, the participants were very comfortable, open, and eager in sharing their thoughts and experiences. Interviews were recorded with consent using a digital voice recorder for accurate documentation and transcription. The interviews were conducted primarily in Filipino. Verbatim transcriptions of the interviews were produced. Codenames were used to mask the identity of the participants. All interview data were kept in an encrypted and password-protected file accessible only to members of the research team.

\section{Data Analysis Procedures}

The interview data were subjected to thematic analysis using the procedures recommended by Braun and Clarke (2006). The analysis began with reading and re-reading the transcripts to ensure familiarization with the data. This was followed by generating initial codes and determining patterns in the data, and reviewing and labeling these to reflect the thematic patterns before writing the report. In analyzing each transcript, particular attention was given to the description of the work context of each of the participants as well as the emerging factors that motivate them to continue working in conflict affected areas despite the dangers that they constantly face.

To enhance the reliability of the analysis, two of the researchers independently analyzed each of the interview transcripts. A series of meetings was conducted to discuss the outcomes of individual analysis. Generated themes and corresponding quoted statements were reviewed until the researchers agreed on the final themes. The main findings were shared with some of the interviewees in a face-toface meeting before writing the results. 


\section{Reflexivity}

In the research planning and implementation stage, the authors constantly had consultation meetings that included sharing of their own backgrounds, experiences, and views about the human rights situation in the country. We thus share the following information about the authors that may be relevant to the readers as they read the presentation of findings in the succeeding results section.

All authors are Filipino citizens who spent most of their lives in the Philippines. Only one of the authors had worked in an NGO that advocates for workers' rights. The other authors do not have any political affiliations and do not have any association with human rights organizations. Most of the authors were aware of the injustices happening, especially in the rural areas of the Philippines, but were nonetheless surprised these were happening on a scale much larger than they had anticipated.

\section{RESULTS}

The participants described their experiences of living "on the edge" as human rights workers deployed in areas affected by armed conflict. The succeeding sections discuss their experiences of risks as well as their motivations for continuing their human rights work.

\section{Risks Faced by HRWs in the Philippines}

The participants shared experiences that were reflective of the risks that they faced as HRWs. First, their work entails deployment to communities experiencing or that has recently experienced violence and abuse. Being in this kind of work environment exposes them to great risks. Second, there were instances when the participants themselves directly experienced intentional violence in the form of harassment and death threats during their deployment.

Deployment to communities exposed to violence and abuse. Participants were deployed to different areas for fact-finding missions on potential human rights violations. Given this, their work spaces are communities that are exposed to violence and abuse. Their 
primary objective was to gather detailed accounts from credible witnesses who were usually members of the local community to verify and document allegations of human rights violations. During their missions, they had to ensure the information they gathered from the witnesses were accurate and detailed. As such, their work environments were naturally high-risk areas. The nature and gravity of risks in the communities are seen in the following stories shared by Art:

Sa ano naman 'to. Saranggani province...biktima ng mga sundalo nag-operation, nagpunta sa community nila, may mga binugbog, may torture case. Yung isa dun di ko makalimutan yung si (name of a member of indigenous tribe) nilasing ng tuba, yung wine, tapos inipit ng plais yung mga kamay para lang umamin. (This happened in Sarangani province... there were victims of military operations. They went to the community and people were beaten up and tortured. I cannot forget (name of a member of indigenous tribe) he was made to drink coconut wine, then they used pliers to press on his hands so he would confess.)

Isang buong sitio, giniba yung bahay, giniba yung eskwelahan, giniba yung barangay hall...Gusto nating malaman ano ba talagang nangyari doon?...Mahirap pumasok. Yung mga taong nasa loob yung lumabas para kausapin kami. Timuay nila. Timuay is parang kung sa ibang tribe mga datu or chieftain nila. Ayon inexplain sa min kung ano nangyari. Since 2012 pa pala. Tapos ang dami na palang namatay. Medyo mahirap yun kasi hindi lang buhay namin e. Buhay nila... Di ko makalimutan kasi kailangan mo i-handle kung paano. Gusto mong i-ano yung issue nila na at the same time hindi sila mapapahamak...Yung mga perpetrators na tukoy ng mga tao ay mga goons ni konsehal at mga goons ni mayor...Mula sa kapitan, konsehal, mayor, governor. Dun pa ko na-ano na may isang insidente na may isang pinatay sa harap lang ng police station. Sabi ko Diyos ko news blackout 'to a. (One whole sitio, they destroyed the houses, school and barangay hall...We wanted to know what happened. It was difficult to go there so the people of the community went to talk to us. Their Timoay. Timoay is similar to a chieftain. They explained to us what happened since 2012. There were a lot of 
killings. It was quite difficult because it's not just our lives, their lives too...I cannot forget that because I need to handle it. I want to push their issue but not put them in danger. The perpetrators identified by the people were goons of the councilor and mayor. From the captain, councilor, mayor and governor. There was even someone killed in front of the police station. I said, my God, this is a news blackout!)

Experiences of direct intentional violence. There are times when risks were more directly felt such as when participants themselves experienced harassment and death threats while conducting factfinding missions. These instances were no longer novel experiences in performing their tasks as seen in the following accounts of Rez, Amy, and Poy:

Rez: Marami...confrotations sa military? Marami. Mga inaaccost kami. Pag may...Pag pumapasok kami sa communities. Usual yan. Yang "pag pumasok kayo...babarilin namin kayo!" Ganyan talaga. Sinasabi nila yun. Almost all of the fact-finding missions that I've joined, search missions. Kahit nga nung nandun...Commissioner on Human Rights. (There were a lot... confrontations with the military? A lot...we were accosted when we go to communities. That's usual. They'll say "if you go in, we will shoot you!" That is how it is...they say that. Almost all of the fact-finding missions that I've joined, search missions. Even if the Commissioner on Human Rights was there.)

Amy: Yung buong community is surrounded by the military, encamped by the military. We had to stay in one of the chapels. Yung nakita lang naming military na visible wala pang 10 personnel, wala pang sampu dun yung visible sa community. Di sila naka-uniform pero they are armed. Siguro ano lang combat fatigue pants lang pero naka-civilian na T-shirts... Nung bandang alas-sinko ng hapon, sabi sa mga marshals namin, marami pa palang nakalibot duon, naka-full battle gear. Kasi bundok yung, as in bundok yung nakapaligid sa min eh. Parang nasa gitna kami ng gubat at bundok. Tapos lahat kaming participants ng fact-finding mission, konti lang kami...wala pa 
kaming 30 katao... natulog kami sa isang chapel, lahat kami dun, at pwede nilang palabasin na ratratin ang chapel na ang pader ay kahoy lang, ratratin yun at pagkinabukasan lagyan ng mga baril tsaka bomba yung loob ng chapel, palabasin na encounter o nagkuta umano yung NPA dun sa ano. Natulog talaga ako na dilat ang isang mata, naka-ready yung text message sa cellphone, ready to send. Isang putok lang yan, send na agad sa mga kinauukulan. Ito yung bilang namin, uh, ito yung bilang ng mga sundalo, ito yung unit ng sundalo, ito yung lugar. (The entire community is surrounded by the military, encamped by the military. We had to stay in one of the chapels. We only saw less than 10 military personnel, those that were only visible to the community. They were not in uniform but they were armed. They were in combat fatigue pants but wearing civilian shirts. Around 5 PM, our marshals said that there were many others surrounding the area in full battle gear. We were surrounded by mountains and forests. There were less than 30 of us...participants in the factfinding mission. We slept in the chapel and they may use open fire on the chapel with wooden walls, fire on us and plant bombs inside the chapel and say that it was an encounter with the NPA camping there. I slept with my eyes open. I was ready to send the text message in my cellphone. One gun shot and I'll send it to our colleagues/authorities - how many people in the mission, number of soldiers, unit of the soldier and the area.)

Poy: Tapos may isa pa kong team, isang fact-finding namin with international friends...From Quezon, yung pinakamalayo, San Andres to Gumaca. Siguro itatravel mo lang siya 2 hours pero kami, alas sais ng umaga, nakaalis kami ng Gumaca alas-dose ng gabi. Alam mo bakit? 7 camps ang hinold kami nang hinold. Yung first camp, rinalihan pa ko. Nagnakaw daw ako ng 720 million na pondo. Ako yun. May mga pangalan ko. Lahat ng fact-finding doon, kung may ginagawa kaming polyeto, may polyeto rin sila sa kin. Poy pangalan ko, Poy Santos, nakalagay dun...Yung camp din nila with the community. Pero syempre di ako natatakot sa kanila, di naman totoo. Nandun ako para tumulong, sa dokumento, makita ko sinasagot ko rin naman 
sila, nag-uusap kami verbally na magkakaharap. (Then I had another team, one fact-finding mission we did with international friends...From Quezon, the furthest we went was to San Andres to Gumapa. You might travel that in two hours, but us, we left at $6 \mathrm{AM}$, and we left Gumapa 12 midnight. Do you know why? We were held by 7 camps along the way. In the first camp, they even rallied against me. They claimed I stole 720 million pesos in funds. Their leaflet had my name. All fact-finding missions there, if we made a leaflet, the soldiers also made a leaflet on me. Poy is my name, "Poy Santos" was written there...Their camp was also with the community. But of course I wasn't afraid of them, because it wasn't true. I was there to help, to document, I answered them, I spoke with them verbally face to face.)

Despite knowing that they put their lives on the line whenever they would go on these missions, people in this line of work seem to have come to terms with their fears. Based on their accounts, these members of Karapatan are not only aware of the risks they face, but they also accept them as part of their work. Cristy shared her thoughts about the risks involved in doing human rights work:

Thoughts ko? Mapanganib. Buwis-buhay siya actually...sobrang risky siya pero once na you're there, parang yung curiosity mo na masagot, na-imbestigahan, o ma-solve yung problema, yung kaso. Yun yung nag-eencourage pa sa kin, nagpupush pa na 'ah kailangan ko to.' No matter what, no matter how risky it is, gusto $k o$. (My thoughts? It is dangerous. It is life-threatening actually... extremely risky, but once you are there, it is like you are curious to get answers, to investigate and solve the problem or the case. These encourage me and push me as if saying, "Ah, I need this." No matter what, no matter how risky it is, I want to do it.)

Despite being aware of and experiencing the risks in engaging in human rights work in areas affected by armed conflict, they remain in their work. According to them, they are motivated to continue with what they are doing because of how they feel when they perform their work, the value they put in it, as well as the inspiration and strength they draw from the communities. 


\section{Intrinsic Motivation}

Majority of the participants said that they joined Karapatan because they felt they had to provide assistance to those who need it most, in one way or another. They feel satisfied whenever they see the positive effects of their work. This was seen in the desire of the participants to conduct missions in the communities they visit without asking for anything in return. Lex mentioned the following:

Kasi alam ko naman yun e, na yung ganitong mga gawain, wala ka namang aasahan. Di ka nagtatrabaho dito para kumita. Nagtatrabaho ka dito para mag-serve ka sa mga victims. (I know that in this line of work, I cannot hope to get anything much in return. You do not work here to earn a good salary. You work here so you can serve the victims.)

This main theme of instrinsic motivation encompasses four subthemes: Altruism, Sense of Fulfillment, Belief in a Just Cause, and Work as Identity.

Altruism. Altruism is an integral part of the internal motivation of the members of Karapatan. This is giving importance to the welfare of others above one's own, which Amy explicitly mentioned during the interview:

Siguro altruistic, malakas level ng altruism ko...Pero talaga when you hear the stories directly from the victims and you read their stories parang telenovela, talagang ano eh, iisipin mo ano ba ang pwede kong gawin para tumulong? And if yung pagpunta doon, buwis-buhay man o hindi, kailangan mong ilabas yung stories ng atrocities when you're conducting factfinding missions, ay gagawin. Ganun. Kahit pa may baby na. Kung kinakailangan. (Perhaps I have a high level of altruism. When you hear the stories directly from the victims and you read their stories like a telenovela, you really think about what can be done to help them. And if you go there, whether or not there is a risk to your life, you have to tell the stories of the atrocities when you are conducting fact-finding missions. Even if I already have a baby, I do it, it's necessary.) 
Notably, some participants have already been involved with projects or occupations advocating for people's rights, providing welfare and service, or humanitarian work before working for Karapatan:

Art: Syempre nung college ako, naging miyembro rin ako ng organization na nagtatackle, nagpapahalaga ng karapatan ng mga estudyante, sa kabuuan sa mga tao, yung student. (Of course when I was in college, I was a member of an organization that tackles and gives importance to students' rights, and people as a whole.)

Rez: Well, my personal history of activism started when I was still in college at the University of the Philippines-Diliman when I became an officer of the student council at the local college level sa College of Arts and Letters, and then the nationwide Alliance of Student Councils in the UP system. So it was there when I was engaged in not only student issues--issues on students' rights and welfare--but on the realities outside the university.

Amy: Nung estudyante kasi ako, aktibista na ko e. Naging socially aware ako through the student publication. Learning about the society, the problems of society and what needs to be done bilang isang member ng lipunan. (When I was a student, I was already an activist. I became socially aware through our student publication. Learning about the society, the problems of society and what needs to be done as a member of society.)

Sense of fulfillment. A sense of fulfillment drives them to continue in their line of work despite its difficult nature. In the communities they visit, they interact with the affected people in the area. The situation of the people leads them to conduct fact-finding missions. Often, whenever they would successfully complete a mission, they see the results and the difference their work has made in the community, and they feel fulfilled. Cristy expressed her fulfillment when she saw how her work contributed to the well-being of the members of their partner communities:

Ang saya lang talaga tignan nung mga batang natutulungan 
mo, mga matatanda na natutulungan mo. Makita ko lang silang ganun, makita ko lang na nagsusurvive sila, nakikita ko lang na natututo sila. (I just feel happy seeing the children that you help, the old people that you help. Just seeing them like that, seeing them survive, seeing them learn.)

The HRWs find their happiness in helping others. Art said that his belief that he is making a change is what fuels his motivation to keep doing the work that he is doing. He shows contentment in what he does and his conviction in his work:

Masaya ako dito. At 'tsaka alam ko na naniniwala akong tama itong ginagawa ko, naniniwala akong nakakatulong ako sa mga tao, naniniwala akong kasabay ng sanlaksa pang ibang mga tao may patutunguhan to. (I am happy here. And I believe that I'm doing the right thing, I believe that I am helping others, I believe that, along with many others, this is going somewhere.)

Believing in a just cause. All participants were clear on their reasons for engaging in human rights work that necessitated going to areas affected by armed conflict. All of them fervently believed what they are doing is right and just, as seen in the following:

Amy: Death can come upon us if we go out into the street, even sa loob ng bahay. You have to understand that...kahit anong oras pwede kang mamatay. Tumigil ang puso mo na hindi inaasahan, pwedeng mangyari yun. Pero ang usapin ay kung ikaw ba ay habang nabubuhay, saan mo pwedeng ilaan yung kakayanan mo, yung talino mo, yung oras mo. Saan mo siya pwedeng ilaan. Uh, personally I chose na ilaan ito sa mas makabuluhang bagay na mas maraming makikinabang. So kung mamatay ako diyan okay lang. Kahit papano may mga natulungan na rin ako...Kaya kung sa fact-finding mission man ay hindi kami mamatay, eh di okay. Mas marami ka pang fact-finding mission na pwedeng puntahan. (Death can come upon us if we go out into the street, even inside our house. You have to understand that...you can die anytime. Your heart suddenly stops beating, that can happen. But the point is while you are alive, to what did you dedicate your capabilities, your intelligence, your time. To what can you dedicate 
those. I chose to dedicate it to meaningful things with which a lot of people may benefit from. So if I die, it's okay. At least I was able to help others...If we don't die in fact-finding missions, then that's okay too. I will be able to go on many more fact-finding missions.)

Art: Kung bakit ako kumilos sa pagsisilbi sa karapatang pantao... Kasi, yun, namulat ako na hindi pantay ang lipunan. Kung kailangan talaga ng pagbabago, kailangan nating magkaisa sa kagaya nating uri na pinagsasamantalahan rin, kagaya nating gusto ng maalwan na bukas...naniniwala akong tama itong ginagawa ko, naniniwala akong nakakatulong ako sa mga tao... (Why am I serving or advocating for human rights...because I am aware that there are inequalities in society. If we want change, we need to unite with those who are exploited, who just like us wants a better future...I believe what I'm doing is right, I know that I am able to help other people...)

Work as identity. Intrinsic motivation also encompasses how Karapatan members see their work. It seems like the work of the Karapatan members is directly linked to how they think of and identify themselves. Cristy talked about how she continued having a certain mode of serving even when she stopped doing human rights (HR) work for a while:

Para bang once na na-hook ka na sa pagseserbisyo, parang once you hear a certain issue, 'di mo mapigilang mag-komento. 'Di mo mapigilang magpayo. 'Di mo mapigilang 'ganito dapat yung gawin. Dapat ganitong steps.' Para pa rin akong nasa $H R$ work kahit wala ako sa HR. (It's like once you're hooked to service work, once you hear a certain issue, you can't help but give comments. You can't help but give advice. You can't help saying, 'this is what you're supposed to do. These are the steps.' It's like I'm in HR work even if I'm not in HR.)

The need to contribute to human rights work even when they are not involved seems to indicate that for Karapatan workers, human rights work is more than just their occupation. It is ingrained in their identity. When Karapatan members go into human rights as a career, 
the work also integrates itself into their personal identity, and it becomes difficult to separate one from the other.

When asked if she had ever questioned her decision to work for Karapatan, Lex expressed, "May mga araw, pero dumaan na din yan. Di na nagbabalik." (There are some days when I do, but they pass. The feeling doesn't come back.)

The members of Karapatan still continue their work because of the meaning it gives to their lives and the fulfillment that they receive from it. As shared by Rez and Amy:

Rez: I think I'm happier as a person and I feel more fulfilled as a member of the middle class knowing that I am living not just for myself and that thought keeps me going.

Amy: Personally, I chose na ilaan ito sa mas makabuluhang bagay na mas maraming makikinabang. So kung mamatay ako diyan okay lang. Kahit papano may mga natulungan na rin ako. (Personally, I chose to give this (life) for a more meaningful thing where more can benefit. So if I die, it's alright. At least I helped others.)

Participants were aware of the imminent danger that they face at work but also expressed that this is what they want and what they have to do. They identify with and find great fulfillment in doing their work, thus continuing to engage in it despite the risks.

\section{Drawing Strength From Partner Communities}

Karapatan workers going to areas with armed conflict also integrate themselves well with the people of the communities that they visit. Based on their accounts, their interaction and relationships with members of the communities gave them the strength to overcome their apprehensions and drove them to continue with their work despite the potential dangers they might encounter. Three subthemes emerged from the data: Tumbasan ang Tapang, Building Relationships With Members of the Community, and the Reciprocal Nature of the Relationships.

Tumbasan ang tapang (matching others' courage). An 
interesting theme that surfaced is the concept of "Tumbasan ang Tapang." A part of the participants' motivation to continue in this line of work is their sensitivity to the experiences of those people in the afflicted areas that they visit. They reason that if the people that they visit are strong enough to thrive in spite of the negative things that they experience, then they, as human rights workers, have no excuse to not be just as strong. These were evident in the sharing of Art and Rez:

Art: Hindi pa sa part ko na [ako] natatakot, nag-aalala, kung hindi sa kanila. Matapang sila e kaya tumbasan ko rin yung tapang nila. Mas dun ka dapat kumilos kasi sila nga matapang, ako pa. (I don't get scared or worry for myself, but for them [people in the community]. They are brave, so I should match their courage. You should act because if they can be brave, so can I.)

Rez: Syempre sino ba namang hindi matatakot doon. Pero ako, ang iniisip ko lang diyan, iniisip ko yung iba. Kung sila nga, mas matindi pa yung dinadaanang sitwasyon eh, sino ba naman ako para matakot. (Of course, who wouldn't be afraid? But for me, I just think of the others. They [referring to people in the community] go through even worse situations, so who am I to get scared?)

Building relationships with members of the community. Rez went further by saying that the social relationships that are built between human rights workers and their partner communities go beyond familial bonds or friendship saying that they are not simply a personal or religious directive, but a higher social contract:

Yung relationship na para kayong magkapamilya. May cohesion, may unity kayo eh with them na alam mong there will always be personal links but it always goes beyond the personal... Kasi yung mag-isip ka para sa iba di lang naman Christian ano yun eh. I think it's also a higher form of social contract. (It is the relationship that is like we are family. There is cohesion, there is unity with them knowing there will always be personal links but it always goes beyond the personal...Because when you think about others, it is not just a Christian practice. I think it is also a higher 
form of social contract.)

Cristy also added:

Tapos natuto sila sa tulong mo, sa tulong ng iba. Natutuwa ako sa ganun. Yun lang naman yung nagpapalakas ng loob sa akin. Tapos nakaka-build ka ng relationship. (So they learn with your help and the help of others. I feel happy. That's just what strengthens my resolve. And then you get to build relationships.)

Reciprocal relationships. The human rights workers going to far-off areas obtain support from the community members in the form of housing and transport, among other things, in return for their work as field researchers for human rights violations. The community members were appreciative of the help that they receive from Karapatan, and Karapatan workers in turn drew strength from the people in the communities. According to Amy:

Pero madali namang ma-overcome yung takot kung may proper and adequate coordination with the local community, local organizations. Talagang pinanindigan kami ng community. (It's easy to overcome the fear if there's proper and adequate coordination with the local community, and local organizations. The community really stands by us.)

It is through these relationships that the social contract can be forged. There exists a unique bond between the participants and their community partners. The desire to help others without expecting tangible benefits and the strength they draw from their relationships with the community push them to go to isolated and conflict-ridden areas. As seen in the participant who has an infant and yet was willing to risk her life for her work, they see their work as a responsibility and as a response to those they consider their own, rather than as a job.

\section{DISCUSSION}

The study captured the experiences of human rights workers in areas afflicted by armed conflict and examined what motivates them to engage in human rights work in these areas. The participants' accounts 
reflected awareness of and having actual experiences of being at-risk due to the presence of armed groups in their areas of operation. Similar to the humanitarian workers in Roth's study (2015), the Karapatan HRWs chose to accept the risks to engage in meaningful work and make a difference in people's lives. Nonetheless, their responses did not reflect the need to escape careers that alienate them from others or working conditions that constrain them, which were among the findings of Roth's study (2015). Rather, their motivations for engaging in human rights work in the different areas in the country show their deep desire to contribute to the betterment of society and to help their countrymen who are in dire need of assistance. They embrace the risks and work in the spirit of altruism (as described by one of the participants). Based on aid work literature, altruism refers to actions performed by an individual that is devoid of self-interest, focused on the needs of the recipient, and may even be disadvantageous to one's self (Fechter, 2012). The shared motivation of the HRWs to engage in their type of work reflect selfless acts that put the interests of the communities above their own safety and even the needs of their families. This is seen in the HRW who was willing to leave her baby to conduct fact-finding missions that are naturally dangerous.

Aside from demonstrating altruism, another subtheme under intrinsic motivation reflected doing the work because of their belief that it is for a just cause. This theme seems to align with identified motivation found by Tassel and Flett (2011) to describe the motivation of humanitarian health professionals working in high-risk scenarios. Similar to the health workers, engaging in human rights work seems to be an avenue to exercise the HRWs internalized value of working for a just cause. Unlike the findings of Tassel and Flett's (2011) study, however, the reasons for engaging in human rights work did not stem from a desire to demonstrate competence or to connect with others (introjected motivation). The HRWs felt the need to engage in this kind of work to respond to the needs of their disadvantaged countrymen.

Participants likewise reported feeling a sense of fulfillment in doing their work. Some of them describe themselves as masaya (happy), reflecting pleasure or enjoyment in the work that they do. This seems to show that aside from identified motivation, the HRWs likewise experience internal motivation or feeling a sense of fulfillment 
and enjoyment on the job that they do (Franco, 2008).

The theme Work as Identity describes how the participants are not motivated by the benefits they receive or their position, but rather by their desire to help despite the risks involved plus their own fulfillment upon seeing the impact of their engagement in the community. The positive meaning that they derive from their work may explain why they highly identify with the work that they do. According to a study done by Franco (2008) on the meaning of work of Filipinos, NGO workers who usually see their work as internally motivating and fulfilling, identify more with their job. They also felt more involved and experienced better job fit.

The theme Drawing Strength From the Community provides insights on how the participants were able to overcome their fears and carry out their day-to-day tasks while in an area affected by armed conflict. Subthemes for drawing strength from the community include Tumbasan ang Tapang, Building Relationships With the Community, and Having a Reciprocal Relationship With the Community. Tumbasan ang tapang, literally meaning "matching others' courage," was an expression used by one of the participants providing a reason to overcome his fears. Building relationships with the community extended beyond a communal bond, to a social contract. Reciprocal relationships with the community is the two-way relationship between the participants and their partner communities, and this shows how they are able to draw strength and support (even through physical provisions such as lodging) from the relationships they share. These themes emphasize the importance of social relationships in human rights work in the Philippines that to our knowledge is not very evident in existing literature. To some extent, the unique bond shared by the participants and the community also serves as a motivation for the participants to continue with their work as they see the members of the community as part of their own family. They were therefore willing to risk their personal safety and security in the service of the community whenever the need arises.

In the Philippines, the relationship between family members is usually considered the strongest among all other relationships (Jocano, 1998). Whereas such relationships are established by blood or the law (e.g., in-laws), this study showed relationships between the HRWs 
and the communities that they serve that are almost indistinguishable from that between family members.

The Filipino's sense of kapwa may also clarify the nature and dynamics of the HRWs' relationships with the community. Kapwa, the Filipino concept of a shared identity, is a central idea in Filipino psychology (Enriquez, 1992; Pe-Pua \& Protacio-Marcelino, 2000). Specifically, the human rights workers' empathy and responsiveness to the struggles faced by the community allowed them to work together towards a common goal. This empathy that translates to concrete actions to assist those whose rights were violated reflects what Enriquez (1992) calls pakikisangkot (getting involved) that later translates to a strong sense of pakikiisa or "being one with" the communities that they work with. These workers go to the communities as outsiders, but they slowly integrate themselves to the community. As the relationship deepens between worker and community, it eventually heightens from being a relationship between ibang-tao or outsiders to hindi-ibangtao or one-of-us.

\section{Limitations and Implications for Future Research}

Although the study presents interesting findings on the experiences and motivations of human rights workers, it is not without limitations. First, there was difficulty finding human rights workers who have been deployed in areas affected by armed conflict for extended periods. This limited the number of participants as well as human rights groups/ organizations that could be engaged in the research. Second, since the question asked about perceived risks was limited to times when the HRWs felt and thought that their lives were in imminent danger when working in an active conflict area, the risks identified may have been constrained by the nature of the inquiry. Thus, adding questions that further explore other perceived risks (e.g., death by natural causes, accidents, and mental health problems) may provide a more holistic perspective.

Aside from improvements on future research that can be applied based on the limitations presented above, more research is needed especially on the unique bond that exists between human rights workers and their partner communities. For example, succeeding studies 
may explore the nature and dynamics of the relationship of HRWs and the communities from the perspective of community members. Succeeding studies may also further document the situations that human rights workers encounter and how they can be supported by their organization and other organizations sympathetic to their cause. The experiences and risks revealed by the respondents likewise point to the need to respect the lives and rights of the HRWs themselves by parties engaged in armed conflict.

Findings of the study may also be used for worker selection and retention programs of Karapatan and other similar organizations. Insights drawn from the study may help human rights organizations determine person-job fit during selection. The organization may probe the applicant's internal motivation and commitment to social justice which seem important given the high risk nature of the work. This seems important especially since external motivations/rewards may not be commensurate to the nature of the work and the risks involved. The organization may also provide the needed support to enable the development of positive and reciprocal relationship with the community as these appear to be important motivational factors for HRWs. Nurturing internal motivation and supporting the development of worker-community relationship may drive retention.

This study examined the motivation of human rights workers (HRWs) deployed in areas affected by armed conflict in the Philippines. Results surfaced the risks that they experience and the intrinsic and extrinsic factors that motivated them to continue with human rights work. Findings may provide insights on how human rights organizations (and other stakeholders) may engage HRWs and support them in the performance of their work.

\section{REFERENCES}

Amnesty International. (2017). The battle of Marawi: Death and destruction in the Philippines (Index No. ASA 35/7427/2017). Retrieved from https://www.amnesty.ie/wp-content/uploads/ 2017/11/Philippines-The-Battle-of-Marawi-ASA-35.7427.2017FINAL.pdf 
Braun, V., \& Clarke, V. (2006). Using thematic analysis in psychology. Qualitative Research in Psychology, 3(2), 77-101. doi:10.1191/1478088706qpo63oa.

Connorton, E., Perry, M., Hemenway, D., \& Miller, M. (2012). Humanitarian relief workers and trauma-related mental illness. Epidemiologic Reviews, 34(1), 145-155.

Daluz, C. (2015, March 24). Armed conflict displaces 120,000 in Mindanao. CNN. Retrieved from http://cnnphilippines.com/ regional/2015/03/23/Armed-conflict-Mindanao-unhcr.html

Deci, E., \& Ryan, R. (2008). Facilitating optimal motivation and psychological well-being across life's domains. Canadian Psychology, 49(1), 14-23.

Eiksson, C., Kemp, H., Gorsuch, R., Hoke, S., \& Foy, D. (2001). Trauma exposure and PTSD symptoms in international relief and development personnel. Journal of Traumatic Stress, 14(1), 205212.

Enriquez, V. (1992). From colonial to liberation psychology. Diliman, Quezon City: University of the Philippines Press.

Fechter, A. (2012). 'Living well' while 'doing good'? (Missing) debates on altruism and professionalism in aid work. Third World Quarterly, 33(8), 1475-1491. doi:10.1080/09700161.2012.698133.

Franco, E. (2008). Framing the meanings of work for Filipinos. In M. Hechanova \& E. Franco (Eds.), Leading Philippine Organizations in a Changing World (pp. 3-15). Quezon City: Ateneo de Manila University Press.

Greenberg, A., Michlig, G. J., Larson, E., Varallyay, I., Chang, K., Enobun, B., . . . Harvey, S. A. (2018). "I knew I could make a difference": Motivations and barriers to engagement in fighting the West African Ebola outbreak among U.S.-based health professionals. Qualitative Health Research, 29(4), 522-532. doi:10.1177/1049732318771306

Holtz, T., Salama, P., Cardozo, B., \& Gotway, C. (2002). Mental health status of human rights workers, Kosovo, June 2000. Journal of Traumatic Stress, 15(5), 389-395.

Human Rights in ASEAN. (2015). [Front Line Defenders] Philippines - Office of human rights organisation Karapatan attacked. Retrieved August 6, 2018, https://humanrightsinasean.info/ 
statements/front-line-defenders-philippines-office-of-humanrights-organisation-karapatan-attacked/

Human Rights Watch. (2012). World report 2012: Philippines (Events of 2011). Retrieved from https://www.hrw.org/worldreport/2012/country-chapters/philippines

Ilagan, J. R. A., Hechanova, M. R. M., Co, T. A. C., \& Pleyto, V. J. Z. (2014). "Bakit ka kumakayod?" Developing a Filipino needs theory of motivation. Philippine Journal of Psychology, 47(1), 117-143.

Indigenous Voices in Asia. (2017). Philippines: 36 Higaonon families in Misamis Oriental flee homes again. Retrieved from https:// iva.aippnet.org/philippines-36-higaonon-families-in-misamisoriental-flee-homes-again/

Jocano, F. (1998). Filipino social organization. Metro Manila, Philippines: Punlad Research House.

Karapatan. (2007). About Karapatan. Retrieved September 1, 2018 from http://www.karapatan.org/about

Karapatan. (2015). Karapatan Monitor (Issue No.2) Retrieved September 1, 2018 from https://www.karapatan.org/files/K\%2O Monitor\%202015\%20Issue\%202_WEB_o.pdf

McFarlane, C. A. (2004). Risks associated with the psychological adjustment of humanitarian aid workers. The Australasian Journal of Disaster and Trauma Studies, 2004(1). Retrieved from https://www.massey.ac.nz/ trauma/issues/2004-1/mcfarlane. htm

Menguito, M. L. (2017). Motivating the Filipino worker. In M. Hechanova, M. Teng-Calleja, \& V. Villaluz (Eds.), Understanding the Filipino Worker and Organization (pp. 116-130). Quezon City: Ateneo de Manila University Press.

Musa, S., \& Hamid, A. (2008). Psychological problems among aid workers operating in Darfur. Social Behavior and Personality: An International Journal, 36(3), 407-416.

Pe-Pua, R., \& Protacio-Marcelino, E. A. (200o). Sikolohiyang Pilipino (Filipino psychology): A legacy of Virgilio G. Enriquez. Asian Journal of Social Psychology, 3(1), 49-71.

Report: Philippines dominates land-rights murders in 2017. (2017, December 16). Philippine Star. Retrieved from https:// www.philstar.com/headlines/2017/12/16/1768956/report- 
philippines-dominates-land-rights-murders-2017

Roth, S. (2015). Aid work as edgework - voluntary risk-taking and security in humanitarian assistance, development and human rights work. Journal of Risk Research, 18(2), 139-155. doi: 10.1080/13669877.2013.875934

Sheik, M., Gutierrez, M., Bolton, P., Spiegel, P., Thieren, M., \& Burnham, G. (2000). Deaths among humanitarian workers. British Medical Journal, 321, 166-168.

Strand, H., \& Dahl, M. (2010). Defining conflict-affected countries. Retrieved from http://unesdoc.unesco.org/ images/0019/001907/190711e.pdf

Tassel, N., \& Flett, R. (2011). Motivation in humanitarian health workers: A self-determination theory perspective. Development in Practice, 21(7), 959-973.

Tayao-Juego, A. (2014, August 13). Husband of slain activist seeks justice for Palparan's victims. Retrieved from http://newsinfo. inquirer.net/628932/husband-of-slain-activist-seeks-justice-forpalparans-victims

United Nations. (2015). Philippines: United Nations Office of the Special Representative of the Secretary-General for Children and Armed Conflict. Retrieved from https:// childrenandarmedconflict.un.org/countries/philippines/

Uppsala Conflict Data Program. (2005). Definitions, sources and methods for Uppsala Conflict Data Program Battle-Death estimates. Retrieved September 1, 2018 from https://ucdp.uu.se/ downloads/old/brd/ucdp-brd-conf-41-2006.pdf

US Department of State. (2017). Philippines 2017 human rights report. Retrieved August 24, 2018 from https://www.state. gov/reports/2017-country-reports-on-human-rights-practices/ philippines_trashed/ 